\title{
JUSTICE BETWEEN THEORY AND PRACTICE
}

\author{
Prof. Ph.D. Daniel AYUCH, \\ Faculty of Orthodox Theology, \\ University of Balamand, \\ LIBAN \\ E-mail: dayuch@gmail.com
}

\begin{abstract}
This article provides a critical approach to justice and social justice as reflected in Scripture and contemporary Orthodox theology. Some readings from the prophets and the wisdom books are commented and related to some key texts in the New Testament, especially those in the Sermon on the Mount. Usually, human beings seek justice because they need an ordered social context. Christians, however, pursue justice mainly because they intend to live according to the Lord's commandment to love the neighbor as themselves. Christians show their faith in their deeds, i.e., they express their orthodoxy through orthopraxy, which is particularly evident in the way they approach their neighbor and the environment where they live.
\end{abstract}

Keywords: justice, social justice, neighborly love, the beatitudes, Georges Khodr;

\section{INTRODUCTION}

The quest for justice is an inherent desire in human nature and has its origins in the mere notion of subsisting within an ordered social context. The idea of justice is part of the common imagination of human beings as Yuval Noah Harari would say (Sapiens 3). Already the Code of King Hammurabi presents the monarch as a just king thanks to divine instruction. Anu, Enlil and Marduk, the great gods of the Mesopotamian pantheon, designated Hammurabi "to make justice prevail in the land, to abolish the wicked and the evil, to prevent the strong from oppressing the weak" (Roth 76). Inspired or not, the canon of this Mesopotamian king persists to this day and is one of the oldest sources of law collections treasured by humankind. Justice is a divine principle that is present not only in the Mesopotamian and Egyptian wisdom, but also in the Biblical wisdom. The divinities have founded and based the entire creation on justice, and they have bestowed on this concept a power of vital character. This order of life called justice rules not only the created world but also the gods. In Sumerian they called it ME, in ancient Coptic they called it Ma'at and in Biblical Hebrew it has always been called Ts ${ }^{\mathrm{e}}$ deqah.

\section{JUSTICE IN REVELATION}

The wisdom of Israel urges its readers to identify this primary order in daily life and to validate it in practice. This order is called "justice". A main axiom for the wise men of the

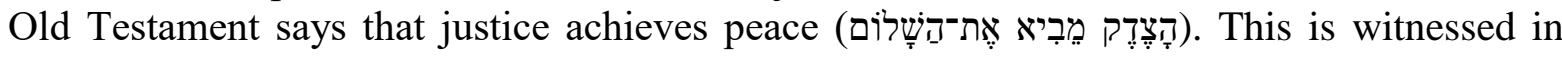
several books of the Bible such as in Isaiah 32:17 "And the work of righteousness will be peace, and the service of righteousness, quietness and confidence forever" or in Psalm 85:10 "Lovingkindness and truth have met together; Righteousness and peace have kissed each 
other." In the Old Testament the quest for justice is not a profane intellectual activity, as perhaps it would be today in a secular world, but it is anchored in the essential principle of wisdom, i.e., the fear of God. Therefore: "Timor domini principium sapientiae" says Proverbs 1:7 and many other biblical quotations. In them one can find the Lord of revelation showing himself as a model of justice and as a source of justice. Hence, for the believers to seek God means to seek justice. Already Psalm 42:1 exclaims this thirst for the just God: "As the deer pants for the water brooks, So my soul pants for You, O God." The entire psalm is an extraordinary text expressing the pain of an exiled man that feels beaten by injustice. This is why in verse 10 the psalmist declares: "I will say to God my rock, "Why have You forgotten me? Why do I go mourning because of the oppression of the enemy?" (Ps 42:9). In other words, the thirst for justice is manifested above all when the human beings experience oppression for themselves. Those who love their neighbor as themselves, a commandment common to both the Old and the New Testament, do also feel a thirst for justice whenever they see a human being suffering under oppression and injustice. Moreover, it is this thirst that moves them to take initiative and go out in search of God. That is why Psalm 43, a complement to the previous poem - both psalms are supposed to be read together-, begins with the exclamation: "Vindicate me, O God, and plead my case against an ungodly nation; O deliver me from the deceitful and unjust man!"

The prophet Amos denounces those who "sell the righteous for money and the needy for a pair of sandals" (Am 2:6. See also 5:11 and 8:5-6). Similarly Isaiah declares: "The Lord enters into judgment with the elders and princes of His people: 'It is you who have devoured the vineyard; the plunder of the poor is in your houses. What do you mean by crushing my people and grinding the face of the poor?" (Is 3:14-15). In the same time, Micah stands up in the name of the Lord against those "who eat the flesh of my people, strip off their skin from them, break their bones and chop them up as for the pot and as meat in a kettle (Mi 3:3). ${ }^{1}$

"Eloi, Eloi lama sabachthani!" A cry that comes out from the heart of man whenever they experience injustice, that is to say, when they experience the absence of God. From the very heart of Jesus on the cross, Mark testifies, this exclamation sprang up, which is at the same time a quotation from the opening verse of Psalm 22. This is one of those few quotations that in the Gospel are first given in Aramaic and then translated into Greek (see Mk 15:34). The psalm appeals for justice and speaks of a righteous man who suffers in the name of justice and for the sake of justice. It is exactly in those moments in which both harshness and weakness collide when justice shows itself as a need. In this sense, the cross and the resurrection are the certainty that God will not leave the oppressed and the persecuted ones without doing justice to them and without granting his servants a triumphant ending.

But does this imply a neglection of the needy in the hope of God's intervention? Should one behave like the evil ones of Psalm 22 and say, "he committed himself to the Lord; let Him deliver him; Let Him rescue him, because He delights in him" (v. 9). Of course not. The essential principle of imitatio Dei rules on all those who believe in the God of revelation and even more on those who believe in Jesus Christ, so that they are called to become an instrument of God and to intervene to save all who suffer injustice, oppression and pain. This principle is already present in the story of creation "rule over the fish of the sea and over the birds of the sky, and over every living thing that moves on the earth" (Gen

\footnotetext{
${ }^{1}$ See more in Verkindere, G. La Justicia en el Antiguo Testamento. CB 105. Estella (Navarra): Verbo Divino. 2001,30 .
} 
$1: 28)$. But it is anchored above all in the famous axiom of Jesus "you are to be perfect, as your heavenly Father is perfect" (Mt 5:48), which the author of Luke formulated as "be merciful, just as your Father is merciful" (Lk 6:36). A saying that has its origins in the Law, especially in Lev 19:2 where we read "you shall be holy, for I the LORD your God am holy." Finally, the alphabetic psalm pair 111-112 explains in the verse that starts with the Hebrew letter Het (verse 4b) the existing synergy between divine and human actions thanks to man's imitation of divine justice. While psalm 111 praises the divine works, the other one commends the righteous person because of their life witness:

\begin{tabular}{|c|c|}
\hline 111:4b & 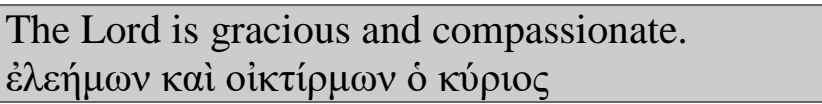 \\
\hline $112: 4 b$ & 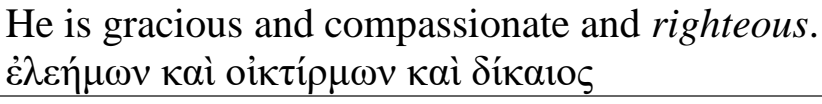 \\
\hline
\end{tabular}

To replace the divine name, the commendation of the virtuous man adds here the most holy title a man can obtain, which is to be a righteous man. The community of believers express their faith by doing good works so that their orthodoxy may be reflected in an orthopraxy, that is to say that they show orthodoxy every time they care for their neighbors, particularly for the needy. Moreover, today it is also necessary to extend this orthopraxy to the environment as well, since Christians are called to take care of nature in every sense: the earth, the air, the water and every living plant and animal in the world.

\section{JUSTICE IN MATTHEW 5:6}

In the Christian tradition the Sermon on the Mount is that greatest text to which we turn to consult on the foundations of Christian faith and work. Precisely in this sermon, Matthew mentions the term justice ( $\delta 1 \kappa \alpha 10 \sigma v ́ v \eta)$ most frequently, i.e., five of the seven times that the term appears in his Gospel. It may not be a high rate of occurrences, yet justice is an immanent and essential component of Matthew's theology. The first time he mentions it is in the fourth beatitude, which refers above all to that yearning for justice that we have been talking about above: "Blessed are those who hunger and thirst for justice, for they will be

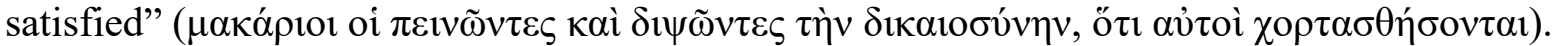

If we make a synoptic comparison of the Beatitude in both Matthew 5:6 and Luke 6:21, we can see how Matthew added the term "justice" as a direct object of hunger and thirst. That is to say, in Luke hunger has the experiential and material connotation of the individual, which is to go through the real feeling of need for food, "Blessed are you who hunger now, for you shall be satisfied" (Lk 6:21). On the other hand, the writer of the First Gospel adds the verb to thirst and the noun justice in order to give to the beatitude a spiritual background that does not take away the material aspect but takes it a step further. That is to say, nothing prevents the recipients of Matthew's beatitude from suffering material hunger, but above all, Matthew awakens that attitude of solidarity and neighborly love that move the disciples to feel hunger and thirst for justice when they see someone suffering oppression and need. Therefore, if we see the entire added expression "to thirst for justice" the educated reader of the Bible recognizes immediately the allusion to Psalms 42-43 that were mentioned earlier and that begin with: "As the deer pants for the water brooks, So my soul pants for You, O God," in which the longing for God is to thirst for justice. Perhaps, that is why St. Gregory of Nyssa in his homily on Matthew 4 in paragraph 5 understands Matthean justice as the ideal of virtue in general. And when Saint John Chrysostom interprets it in his commentary as a special virtue against greed, he was without a doubt referring to social 
justice, that is, to the generous administration of goods in favor of those in need (Commentary to Matthew 15:3).

The Biblical scholar Urlich Luz, an important representative of modern exegesis on the Gospel according to Matthew, affirms that the term justice that appears in the fourth and eighth beatitudes is to be understood as a reference to human behavior. Thus, therefore, "being hungry and thirsty" can mean both "longing for" and "striving to" something. Thus, classical and modern exegesis see in this text of Matthew a call to social commitment. To hunger and thirst for justice is therefore to strive constantly, day by day, in a quest for understanding virtue and practicing a true Christian behavior.

\section{A SUCCINCT THEOLOGICAL PERSPECTIVE}

Based on the prophetic Biblical texts, the former Archbishop of Mount Lebanon, H.E. Georges Khodr, points out in one of his articles written in year 2009 that justice must be measured by the way it behaves towards the poor. ${ }^{2}$ This is in itself a Biblical principle that, as he points out, is to be read in the Book of Isaiah, although Amos already had it clearly envisaged as well, beside all the other prophets. Justice in society is reflected mainly in the treatment they give to the weaker, in the readiness they show to assist those who can neither give back nor reward with material possessions. When the authorities of a society and their individuals help out of conviction, because they need to do good to others, then a service of love is being offered, as Bishop Khodr says. Therefore, justice manifests itself in the practice of the commandment of neighborly love. These words sound quite difficult to be put in practice, but they are important for those Christians who commit themselves to follow Jesus and try to love not only those who are close but also their enemies (Neighborly love: Mt 5:43, 19:19; Enemy love: Mt 5: 44; Lk 6:27).

In another article of year 2010 H.E. Georges Khodr says that a righteous ruler is a ruler who confesses God's authority and who follows His commandments. In this case, the ruler becomes a kind of God's instrument to fulfill His justice on earth. Justice is not necessarily present in what the majority votes neither in a government of consensus, because, as Khodr says, one can make a nation agree on hatred and be in favor of injustice. ${ }^{3}$ Something that has been seen repeatedly in history and the Nazi Germany can be a clear example. Only God has a justice that is absolute and that therefore does not vary in favor of the conveniences of some, but rather acts, according to our Christian theology, by the principles of love and mercy. Therefore, it is important that it be God, the God of revelation, the first and highest model of justice for man.

On a different note and in an era in which collective responsibility is a must and sustainability projects with commitments that protect the environment worldwide are claimed by the younger generations, Staretz Zosima from "The Brothers Karamazov" illustrates well enough our responsibility to be just and to do justice. We are all responsible for the destiny of every human being. Zosima says:

"There is one way for you to overcome these obstacles: take firm hold of yourselves and make yourselves answerable for all men's sins. This is also the truth, friends! For as soon as a man sincerely accepts the idea that he is answerable for the sins of all men, he will realize that, indeed, he is answerable for everybody and everything" (Karamazov II.VI.G).

2 "Woe to who is cursed by the poor citizen." Annahar Newspaper, 7 May 2018. ONLINE. Reprinted in: https://goo.gl/rSqZmQ (In Arabic).

3 "Authority." Annahar Newspaper, 19 June 2010. ONLINE. Reprinted in: https://goo.gl/ZwVYRx (In Arabic). 
This teaching on shared responsibility should not be used to incriminate others and consider ourselves free from sin, as if all others were guilty and we were not, but above all it should serve to awaken a feeling of solidarity and to promote a spirit of community work.

\section{CONCLUSIONS}

Last year an internationally famous Lebanese movie with the title "Capernaum" has critically and acutely pointed out the level of social injustice that exists in Lebanese society. Above all, it has accused an indifferent society and a cadre of leaders who do not engage beyond the needed formalities, being more concerned in appearing to observe justice than to really practice justice; the polar opposite of Jesus' instruction: "Beware of practicing your righteousness before men to be noticed by them" (Mt 6:1).

The call "Justice, and only justice, you shall pursue" in Deuteronomy 16:20, is a Biblical imperative that the great saints in different parts of the world sought to fulfill. Let's mention in the Orthodox Church Saint Nektarios of Aegina and Saint Nicholas of Mira and also Saint Juliana of Lazarevo. From the West, one can mention Saint Francis of Assisi, Mother Teresa of Calcutta and also Saint Maximilian Kolbe. These men and women did not go out to "change the world" in the political sense of the phrase, nor did they need a rational motivation based on humanist solidarity and philanthropy. These blessed Christians are clear role-models, who understood the imperative of behaving with justice and wanted to live following the footsteps of the Lord with the only desire of contributing with a grain of sand to the propagation of the Christian message of salvation to those around them.

\section{BIBLIOGRAPHY:}

[1] Dostoyevsky, Fyodor, and Andrew H. MacAndrew. The Brothers Karamazov. New York: Bantam Books, 2009. EPUB.

[2] Guillaumin, Jean Y. Gabrielle Parent, and Adalbert G. Hamman. Grégoire De Nysse Commente Les Béatitudes. Paris: Desclée de Brouwer, 1979. Print.

[3] Harari, Yuval Noah. Sapiens: a brief history of humankind. New York: Harper Perennial, 2018.

[4] John Chrysostom. Homilies on the Gospel of St. Matthew. Translated by Philip Schaff. Edinburgh: T \& T Clark, 1991. Print.

[5] Khodr, Georges. "Authority." Annahar Newspaper, 19 June 2010. ONLINE. Reprinted in: https://goo.gl/ZwVYRx (In Arabic).

[6] Khodr, Georges. "Woe to who is cursed by the poor citizen." Annahar Newspaper, 7 May 2018. ONLINE. Reprinted in: https://goo.gl/rSqZmQ (In Arabic).

[7] Luz, Ulrich. Matthew 1-7: A Commentary. Minneapolis, MN: Fortress Press, 2007. Print.

[8] Roth, M. Law Collections from Mesopotamia and Asia Minor. Atlanta: SBL. 1997.

[9] Verkindere, G. La Justicia en el Antiguo Testamento. CB 105. Estella (Navarra): Verbo Divino. 2001. 